\title{
Optical Characteristics of Tin Oxide Thin Films Doped with Indium and Aluminum Using the Sol-Gel Spin Coating Technique
}

\author{
Aris Doyan ${ }^{1,2^{*}}$, Susilawati ${ }^{1,2}$ and Haris Munandar ${ }^{1}$ \\ ${ }^{1}$ Master of Science Education Program, University of Mataram, Lombok, West Nusa Tenggara, Indonesia \\ ${ }^{2}$ Physics Education, FKIP, University of Mataram, Lombok, West Nusa Tenggara, Indonesia \\ *Corresponding author. Email: aris_doyan@unram.ac.id
}

\begin{abstract}
The aims of this research are to understand the optical characteristics of $\mathrm{SnO}_{2}$ doped with Indium and Aluminum $\left(\mathrm{SnO}_{2}: \mathrm{In}+\mathrm{Al}\right)$ using the sol-gel spin coating technique. Optical characteristics of $\mathrm{SnO}_{2}: \mathrm{In}+\mathrm{Al}$ thin films were measured by UV-Vis Spectrophotometer. The optical characterization results showed that the $\mathrm{SnO}_{2}: \mathrm{In}+\mathrm{Al}$ thin films had an increase in transmittance from $(68.6-78.3) \%$ at a wavelength of $300-470 \mathrm{~nm}$ and an increase in absorbance at a wavelength of $295 \mathrm{~nm}$ from $4.34-5.00$ with the increase in the percentage of doping. This shows the thin layer absorbs the maximum waves at a wavelength of $295 \mathrm{~nm}$. The increase in the doping percentage causes the energy gap of $\mathrm{SnO}_{2}$ thin films is decreasing. The direct energy gap decrease from 3.58 to $3.54 \mathrm{eV}$ and the indirect energy gap decrease from 3.90 to $3.87 \mathrm{eV}$. The energy of optical activation of the $\mathrm{SnO}_{2}$ thin films decreases from 0.97 to $0.86 \mathrm{eV}$ when increasing the doping percentage. This research has indicated that $\mathrm{SnO}_{2}: \mathrm{In}+\mathrm{Al}$ thin films has a low energy gap and high transmittance so that it belongs to be high-quality thin films.
\end{abstract}

Keywords: Aluminum, Indium, Optical Characteristics, Sol-Gel, Spin-Coating, Thin films, Tin oxide.

\section{INTRODUCTION}

Current technological developments cannot be separated from the support of the existence of semiconductor materials. The use of semiconductor materials is mostly found in electronic devices. Tin oxide $\left(\mathrm{SnO}_{2}\right)$ is a semiconductor material that is often used. This $\mathrm{SnO}_{2}$ semiconductor is included in an N-type semiconductor. The size of semiconductor material can be made from micrometer to nanometer, which is in a thin layer form. A gap of thin layer energy made from $\mathrm{SnO}_{2}$ is large for a semiconductor, which is $3.60-3.98$ $\mathrm{eV}[1,2]$. Modifications made to semiconductor materials can make the semiconductor materials using more diverse.

Thin-film semiconductors are widely used as touch screens, solar cells [3], and sensors of gas [4]. To make this thin layer function better, an additional substance (doping) is needed to decrease the energy gap. Some doping that has been added to $\mathrm{SnO} 2$ is Aluminum [5], Fluoride Dehydrate [6], Cesium [7], Aluminum-Zinc [8], Indium [9], and Fluorine [10]. Some research results that add doping to $\mathrm{SnO}_{2}$ thin films have shown that the conductivity of doped thin films has increased. In other words, the energy gap is decreasing.

Indium is used as doping in $\mathrm{SnO}_{2}$ because Indium reflexes to temperature [11], has fairly high transparency [12], and the synthesis process can be carried out at low temperatures [13]. Meanwhile, Aluminum is used as doping because Aluminum produces high transparency in the range of visible light [14]. The availability of $\mathrm{Al}$ material in nature is very abundant. Besides, Aluminum has a resistance to oxidation (not corrosive), strong and lightweight.

Some techniques in making thin films include RF sputtered [15], pulsed laser deposition [16], reactive 
magnetron sputtering [17], RF plasma enhanced reactive thermal evaporation [18], DC and RF sputtering [19] which are efficient in electric power [20], a spin-coating technique [21], and dip-coating [22]. The spin-coating is the most economical, simplest, and efficient technique [23]. This method can produce thin films with highquality with a thickness that can be adjusted through playback time and rotational speed [24].

\section{EXPERIMENTAL}

In principle, the process of synthesizing thin films with the sol-gel spin-coating technique uses centrifugal force to spread the solution used as the base material evenly on the surface of the substrate used. The solution used as a base for making thin films is dripped on a glass substrate and then rotated until the solution is spread evenly on the surface of the glass. The rotating speed used is $2000 \mathrm{rpm}$. The playback time used is 3 minutes. That speed and playback time have produced a thin layer with a thickness of about $60 \mathrm{~nm}$. This result can be obtained from Figure 1 .

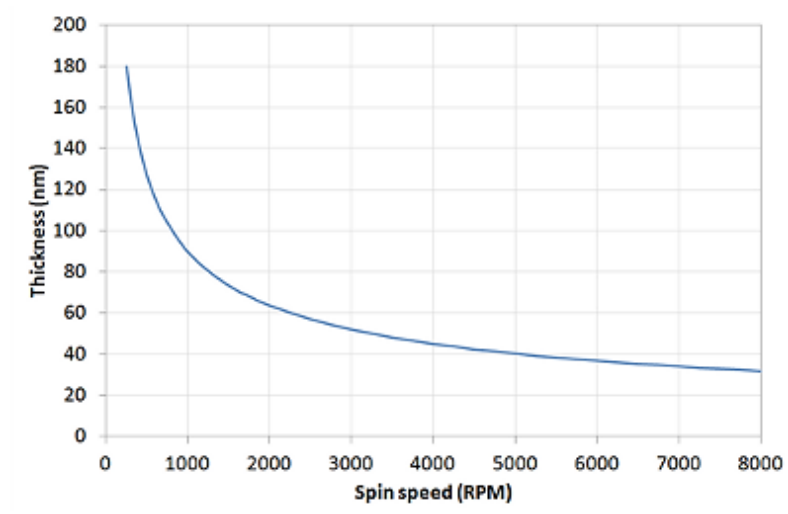

Figure 1 Graph of the relationship between film thickness and rotation speed [25].

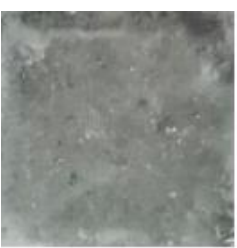

(a)

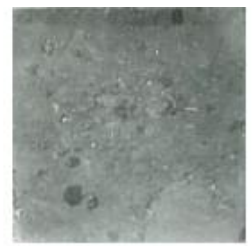

(b)

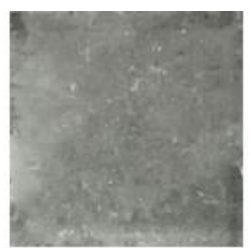

(c)

The basic material used as a thin layer in this study was $\mathrm{SnO}_{2} .2 \mathrm{H}_{2} \mathrm{O}$ which was doped with $\mathrm{InCl}_{3} .4 \mathrm{H}_{2} \mathrm{O}$ and $\mathrm{AlCl}_{3}$ which was dissolved using $\mathrm{C}_{2} \mathrm{H}_{5} \mathrm{OH}$. The main ingredient of $\mathrm{SnO}_{2}$ thin film was doped with a mixture of Indium and Aluminum with a percentage of doping mass of $0,5,10,15,20$, and $25 \%$. The optical characteristics of the resulting thin film consist of transmittance and absorbance. Measurement of transmittance and absorbance of thin films using UVVis Spectrophotometer in a wavelength range from 200 $\mathrm{nm}$ to $800 \mathrm{~nm}$.

The energy gap amount is determined from the value of the absorbance. The energy gap is the lowest energy absorbed by material so that electrons can move to the conduction band from the valence band. The energy gap can be determined from the slope of the graph $(\alpha h v)^{n}$ to the photon energy $(h v)$. The energy gap consists of direct optical energy gap $(n=1 / 2)$ and indirect optical energy gap $(n=2)$ [26].

The energy gap can be determined by using the equation

$\alpha(v) h v=C\left(h v-E_{g}\right)^{n}$

Note: $h v$ is the initial energy of the photon, $h$ is the Planck's constant, $E_{g}$ is the energy gap, and $C$ is constant.

\section{RESULT AND DISCUSSION}

Figure 2 below shows the thin films $\mathrm{SnO}_{2}: \mathrm{In}+\mathrm{Al}$ with doping percentages of $0,5,10,15,20$, and $25 \%$ with the number of layers 1 at a heating temperature of $100{ }^{\circ} \mathrm{C}$

The optical characteristics obtained from the UVVis Spectrophotometer are the absorbance and transmittance of the $\mathrm{SnO}_{2}$ thin film doped with a mixture of Indium and Aluminum.

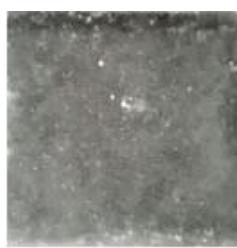

(d)

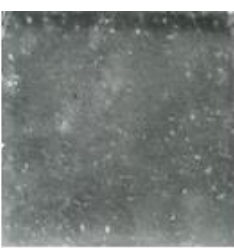

(e)

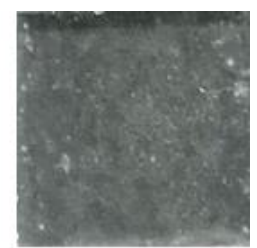

(f)

Figure $2 \mathrm{SnO}_{2}: \mathrm{In}+\mathrm{Al}$ thin films with Doping (a). 0:100, (b). 5:95, (c). 10:90, (d). 15:85, (e). 20:80, (f). 25:75\%.

\subsection{Measurement of Transmittance and Absorbance}

The results of absorbance and transmittance of $\mathrm{SnO}_{2}: \mathrm{In}+\mathrm{Al}$ thin films with the number of layers 1 at a heating temperature of $100{ }^{\circ} \mathrm{C}$ were tested using UV-Vis Spectrophotometer shown in figure 3.
Figure 3 (a) shows the transmittance obtained from $\mathrm{SnO}_{2}: \mathrm{In}+\mathrm{Al}$ thin films with doping concentrations of 0 , $5,10,15,20$, and $25 \%$ respectively have an impact in increasing the transmittance of $\mathrm{SnO}_{2}$ thin films. This phenomenon has similar results to previous studies on thin films doped with Indium [27, 28]. Besides, this study also has results similar to previous studies using Aluminum doping [29]. 
The transmittance increases at a wavelength of $300-$ $470 \mathrm{~nm}$. The maximum value of transmittance at 470 $\mathrm{nm}$ wavelength from the lowest doping concentration to the highest is $74.5 ; 68.6 ; 72.1 ; 71.6 ; 78.3$; and $74.8 \%$. This shows that the movement of electrons occurs due to the presence of photon energy at a wavelength of 300 - $470 \mathrm{~nm}$. Whereas at wavelength $470-600 \mathrm{~nm}$ the graph of transmittance looks flat, which means that the wavelength of $470-600 \mathrm{~nm}$ photons does not occur in the movement of electron jumps.

Figure 3 (b) shows the increase of the doping percentage causes the absorbance of the thin film to

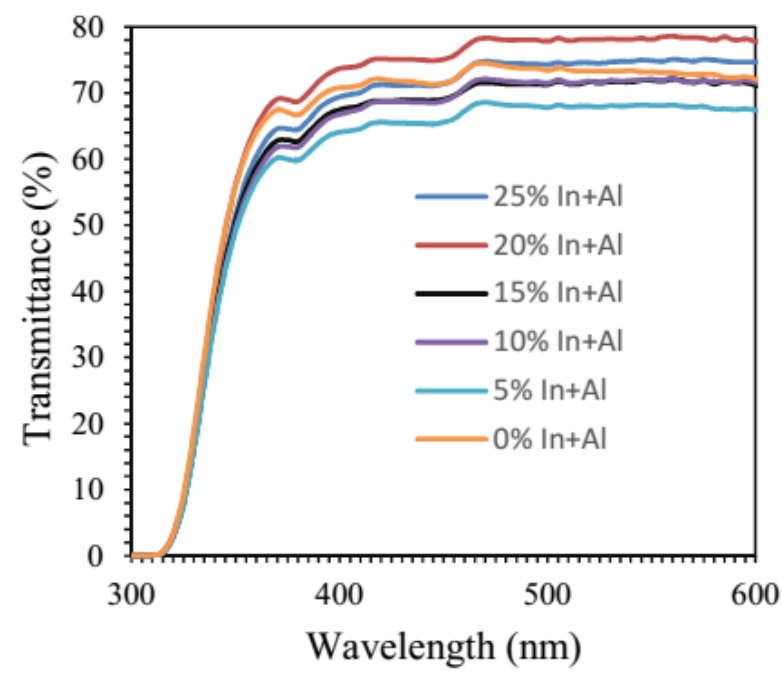

(a) increase at wavelength $290-295 \mathrm{~nm}$. The absorbance at a wavelength of $295 \mathrm{~nm}$ for doping percentage $0,5,10$, 15,20 , and $25 \%$ is $4.67 ; 4.34 ; 5.00 ; 4.58 ; 4.50$; and 4.59. Absorbance value decrease after reach a wavelength of $295 \mathrm{~nm}$. In general, the increase of doping percentage makes the transmittance of $\mathrm{SnO}_{2}: \mathrm{In}+\mathrm{Al}$ increases, and the absorbance of $\mathrm{SnO}_{2}: \mathrm{In}+\mathrm{Al}$ thin films decreases. This is due to the presence of $\mathrm{In}$ and $\mathrm{Al}$ doping in the $\mathrm{SnO}_{2}$ structure which causes the density of the crystal structure to increase so that electrons from light can move more rapidly.

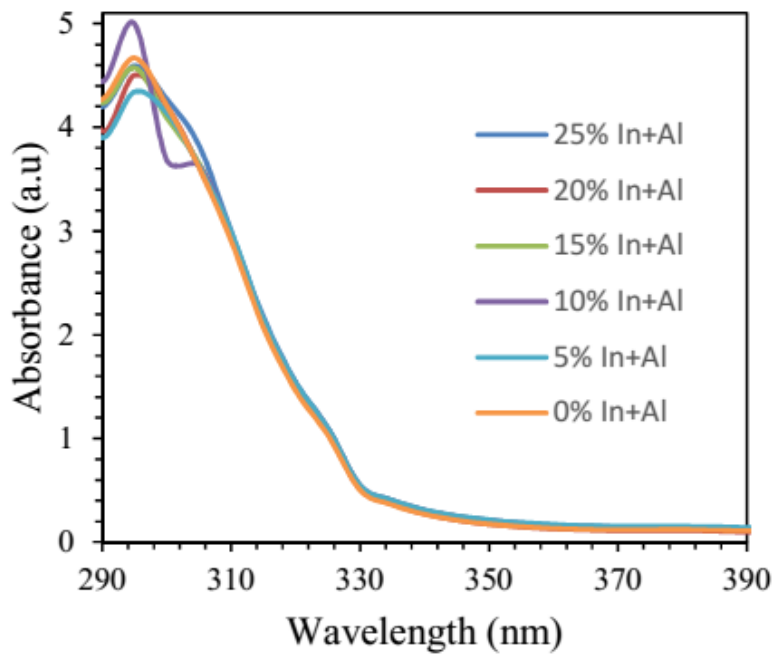

(b)

Figure 3 (a) Transmittance of $\mathrm{SnO}_{2}: \mathrm{In}+\mathrm{Al}$ thin films with doping percentage (\%) 0, 5, 10, 15, 20, and 25\%, (b) Absorbance of $\mathrm{SnO}_{2}: \mathrm{In}+\mathrm{Al}$ thin films with percentage of doping 0, 5, 10, 15, 20, and $25 \%$.

\subsection{Calculation of Energy Gap}

The energy gap of the thin layer is determined from the analysis of the direct optical energy gap and the indirect optical energy gap. The absorbance amount of $\mathrm{SnO}_{2}: \mathrm{In}+\mathrm{Al}$ thin films is used to find the energy gap of the thin films. The energy gap is determined from the graph slope of the energy of the photon $(h v)$ to $(\alpha h v)^{n}$.

\subsubsection{Direct Optical Energy Gap $(n=1 / 2)$}

Figure 4 shows the doping of Indium and Aluminum to the $\mathrm{SnO}_{2}$ thin layer reduces the direct optical energy gap from $3.58 \mathrm{eV}$ to $3.54 \mathrm{eV}$. The higher percentage of doping: $0,5,10,15,20$, and $25 \%$ results in an energy gap being reduced from $3.58 ; 3.56 ; 3.55 ; 3.54 ; 3.56$; and $3.55 \mathrm{eV}$.

\subsubsection{Indirect Optical Energy Gap $(n=2)$}

Figure 5 shows the slope graphs of each doping variation. The addition of doping causes the gap of indirect energy to thin film to decrease, starting from $3.90 ; 3.88 ; 3.88 ; 3.88 ; 3.88$; and $3.87 \mathrm{eV}$.
Figure 6 shows that the direct optical energy gap is lower than the indirect optical energy gap. The direct optical energy gap decreasing from $3.58 \mathrm{eV}$ to $3.54 \mathrm{eV}$. The indirect optical energy gap decreased from $3.90 \mathrm{eV}$ to $3.87 \mathrm{eV}$.

The position of the valence band and conductivity of the direct optical energy gap is in one phase, whereas the valence band and conductivity for the indirect energy gap are in different phases. In the direct optical energy gap, electrons move to the conduction band from the valence band in a straight line so that the electrons arrive at the conduction band faster. Meanwhile, in the indirect optical energy gap, there is a jump of electrons to the conduction band from the valence band in a nonstraight line, so the electrons arrive at the conduction band slower.

This causes the direct optical energy gap to be smaller than the indirect optical energy gap. The reduction in the energy gap is caused by the presence of impurities in the $\mathrm{SnO}_{2}$ structure, namely doping given in the form of Indium and Aluminum which makes a new recombination center with lower emissions of energy. 


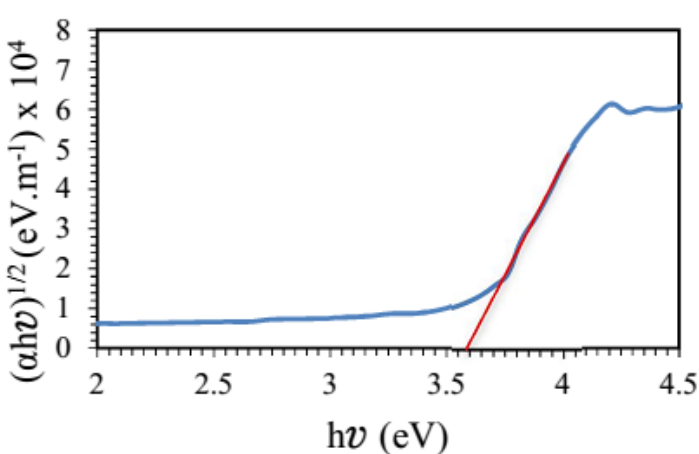

(a)

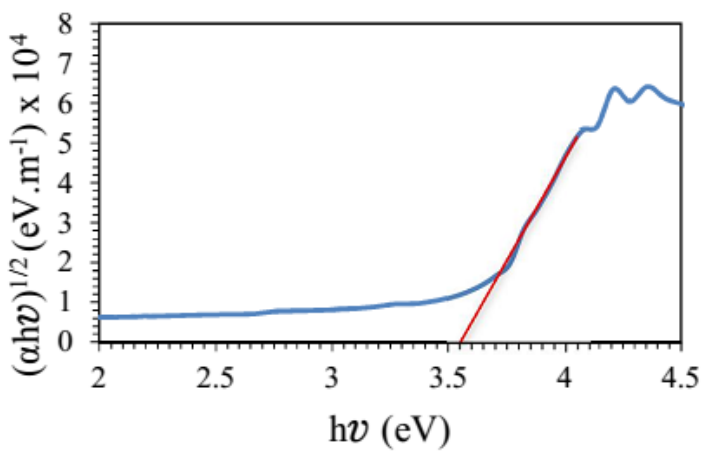

(c)

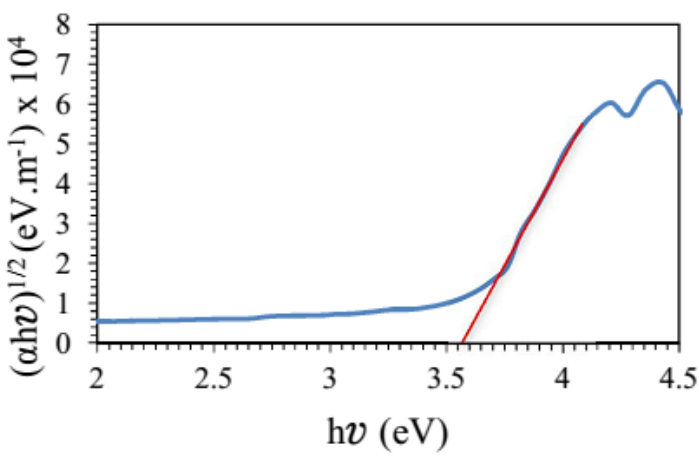

(e)

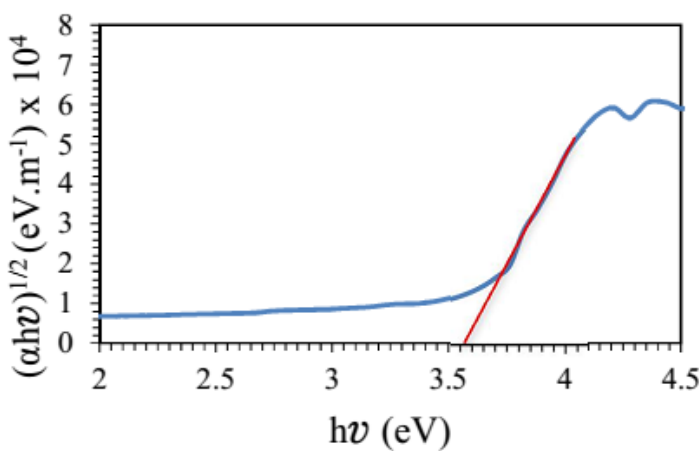

(b)

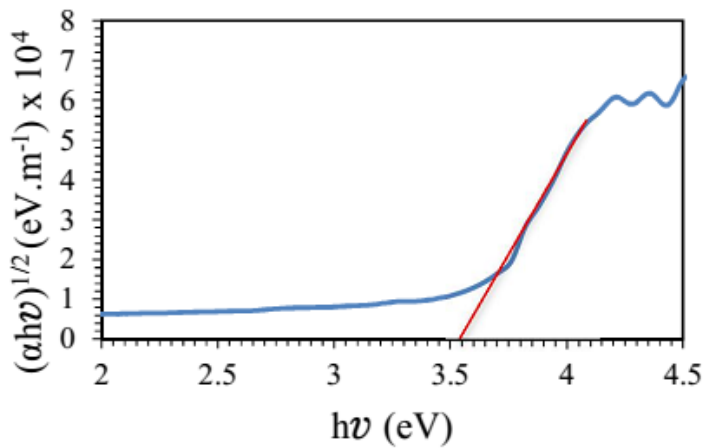

(d)

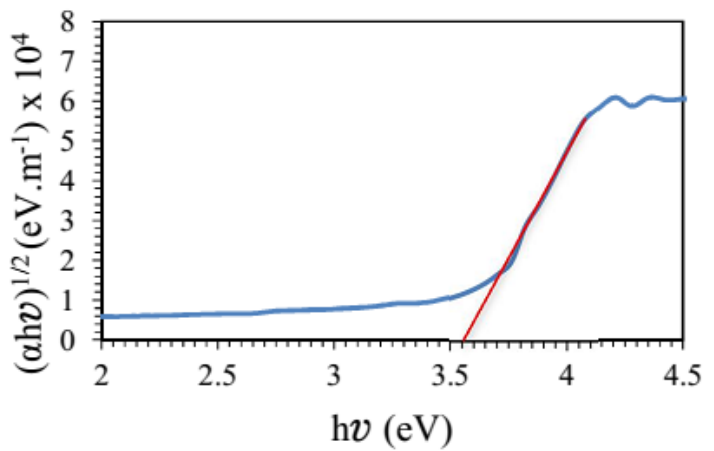

(f)

Figure 4 Allowed transition $(\alpha h v)^{1 / 2}$ versus $h v$ on $\mathrm{SnO}_{2}: \mathrm{In}+\mathrm{Al}$ thin films (a) $0 \%$, (b) $5 \%$, (c) $10 \%$, (d) $15 \%$, (e) $20 \%$, and (f) $25 \%$. 


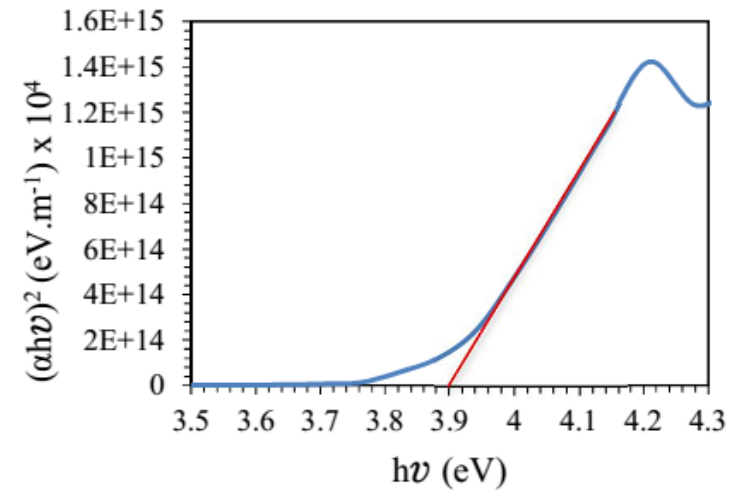

(a)

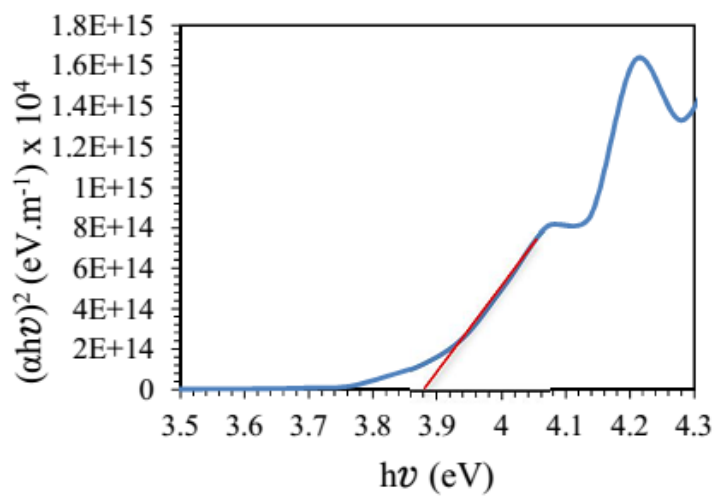

(c)

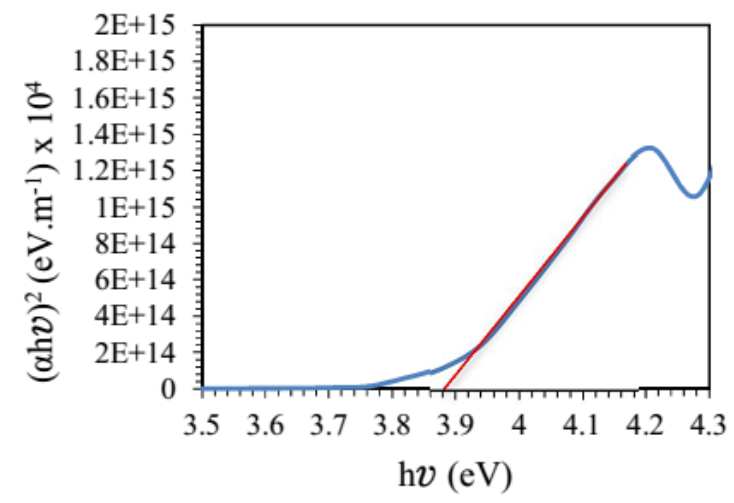

(e)



(b)

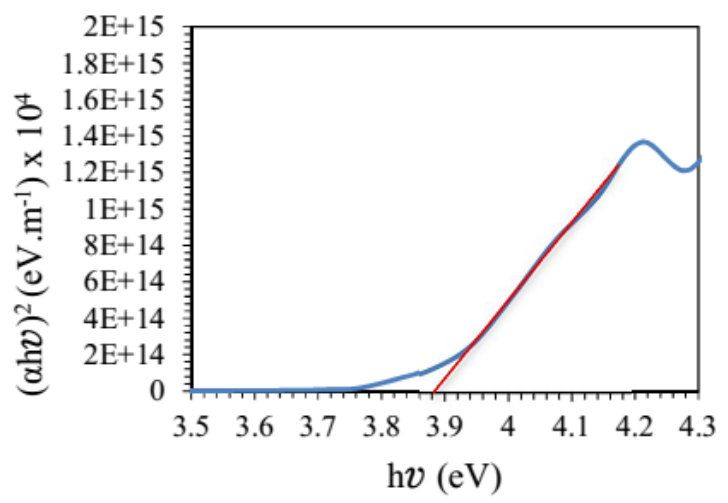

(d)

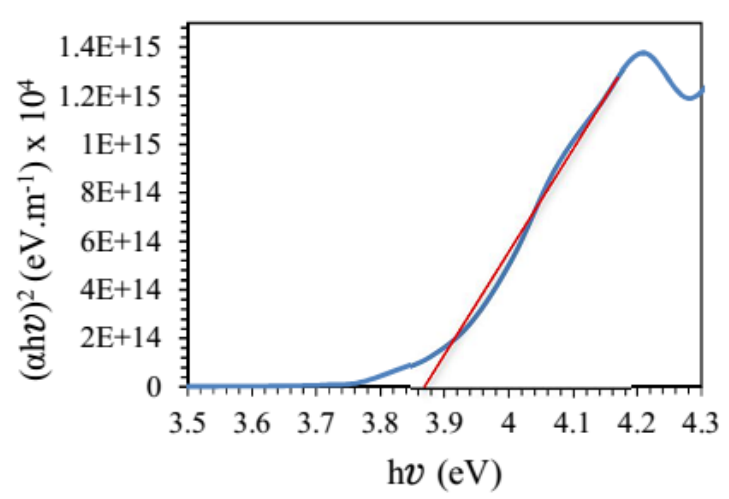

(f)

Figure 5 Allowed transition $(\alpha h v)^{2}$ versus $h v$ on $\mathrm{SnO}_{2}: \mathrm{In}+\mathrm{Al}$ thin films (a) $0 \%$, (b) $5 \%$, (c) $10 \%$, (d) $15 \%$, (e) $20 \%$, and (f) $25 \%$.

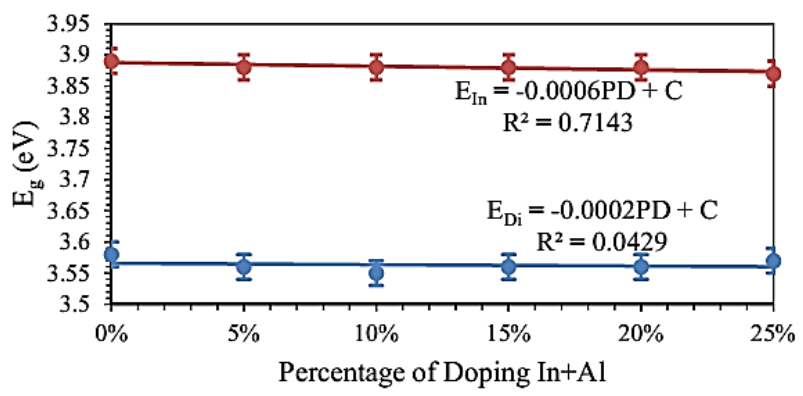

Figure 6 The direct and indirect optical energy gap of $\mathrm{SnO}_{2}: \mathrm{In}+\mathrm{Al}$ thin films.

\subsection{Optical Activation Energy}

The value of the optical activation energy is determined from the slope value $(m)$ of the photon energy graph for $\ln (\alpha)$. The amount of optical activation energy $E_{a}=1 / m[30]$.

Gradient graph $(m)$ of each percentage of doping $(0$, $5,10,15,20$, and $25 \%$ ), namely 1.063 each; 1.027; $1.070 ; 1.072 ; 1.168$; and 1.130 . From the value of gradient, the activation energy of optic in figure 6 is 
$0.94 ; 0.97 ; 0.94 ; 0.93 ; 0.86$; and $0.88 \mathrm{eV}$. The reduced activation energy causes electrons to move faster than the valence band to the conduction band in the material so that the material becomes more semiconductor [31, 32].

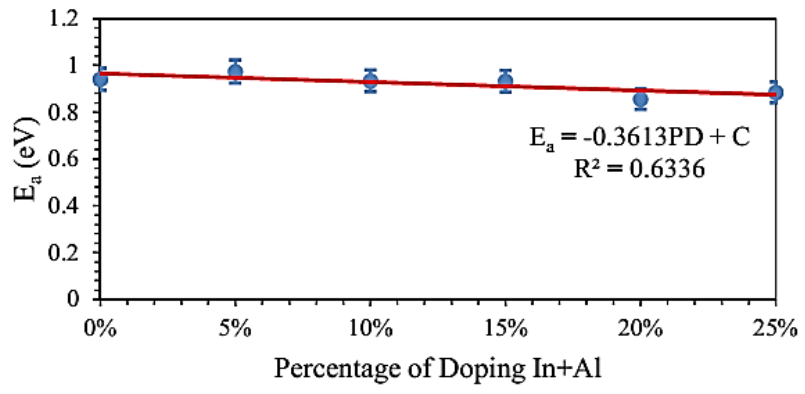

Figure 7 The graph of the doping percentage versus activation energy of $\mathrm{SnO}_{2}: \mathrm{In}+\mathrm{Al}$ thin films.

\section{CONCLUSION}

The addition of doping percentages of Indium and Aluminum to $\mathrm{SnO}_{2}$ thin films causes the transmittance of thin films to increase from $68.6-78.3 \%$ at a wavelength of $300-470 \mathrm{~nm}$, and the absorbance is decreased after reach a wavelength of $295 \mathrm{~nm}$. The gap between the $\mathrm{SnO}_{2}$ thin film energy bands decreases with increasing doping concentrations of Indium and Aluminum. The reduction in energy gap from $3.58 \mathrm{eV}$ to $3.54 \mathrm{eV}$ and optical activation energy from $0.97 \mathrm{eV}$ to $0.86 \mathrm{eV}$ makes high-quality thin films.

\section{AUTHORS' CONTRIBUTIONS}

Aris Doyan has contributed to making articles and data analysis. Susilawati contributed to the data analysis. Haris Munandar has contributed to data collection and data processing for making complete articles.

\section{ACKNOWLEDGMENTS}

We would like to thank the Indonesian Ministry of Research and Higher Education who has provided funding for the Master's Thesis Research. We would also like to thank the Analytical Chemistry Laboratory, Mataram University for giving permission in the sample making process, and the Integrated Laboratory, Diponegoro State University for assisting in collecting UV-Visible sample data.

\section{REFERENCES}

[1] Aziz, M. Abbas, S. S. Baharom, W. R. W. 2013. Size-controlled synthesis of $\mathrm{SnO}_{2}$ nanoparticles by sol-gel method. Journal Materials Letters, 91 (2013) 31-34
[2] Erken, Ö, Gümüş, C. 2018. Determination of The Thickness and Optical Constants of Polycrystalline $\mathrm{SnO}_{2}$ Thin Film by Envelope Method. Adiyaman University Journal of Science dergipark.gov.tr/adyusci, 8 (2) (2018) 141-151

[3] Doyan, A. Susilawati, Imawanti, Y. D. Gunawan, E. R. Taufik, M. 2018. Characterization Thin Film NanoParticle of Aluminum Tin Oxide (AlTO) as Touch Screen. IOP Conf. Series: Journal of Physics: Conf. Series, 1097 (2018) 012009

[4] Degler, D. Barz, N. Dettinger, U. Peisert, H. Chassé, T. Weimar, U. Barsan, N. 2016. Extending the toolbox for gas sensor research: Operando UVvis diffuse reflectance spectroscopy on $\mathrm{SnO}_{2}$-based gas sensors. Journal. Sensors and Actuators B, 224 (2016) 256-259

[5] Doyan, A., Susilawati, Imawanti, Y. D. 2017. Synthesis and Characterization of $\mathrm{SnO}_{2}$ Thin Layer with a Doping Aluminium is Deposited on Quartz Substrates. AIP Conference Proceedings, 1801, 020005. DOI 10.1063/1.4973083

[6] Rahal, Achour. Benramache, Said. Benhaoua, Boubaker. 2013. Preparation of n-type Semiconductor $\mathrm{SnO}_{2}$ Thin films. Journal of Semiconductors, Vol. 34 No. 8

[7] Kaviyarasu, K. Manikandan, E. Kennedy, J. Ladchumananandasiivam, R. Gomes, U.U. Maaza, M.Mola, G. T. 2017. Improved, Photon Conversion Efficiency of $\left(\mathrm{SnO}_{2}\right)$ Doped Cesium Oxide (Cs) Nanofibers for Photocatalytic Application Under Solar Irradiation. Springer International Publishing AG 2017A.Y. Oral and Z.B. Bahsi Oral (eds.), 3rd International Multidisciplinary Microscopy and Microanalysis Congress (InterM), Springer Proceedings in Physics 186

[8] Ikraman, N. Doyan, A. Susilawati. 2017. Growth of $\mathrm{SnO}_{2}$ Films with Al-Zn Doping Using the DipCoating Sol-Gel Technique. Jurnal Pendidikan Fisika dan Teknologi, Vol. 3, No. 2. (ISSN. $2407-$ 6902)

[9] Benouis, C. Benhaliliba, M. Yakuphanoglu, F. Juarez, A. S. 2011. Physical Properties of Ultrasonic Sprayed Nanosized Indium Doped $\mathrm{SnO}_{2}$ Films. Journal Elsevier Synthetic Metals, 161 (2011) 1509-1516

[10] Muliyadi, L. Doyan, A. Susilawati. Hakim, S. 2019. Synthesis of $\mathrm{SnO}_{2}$ Thin Layer with a Doping Fluorine by Sol-Gel Spin Coating Method. Jurnal Penelitian Pendidikan IPA (JPPIPA), 5 (2) 2019: 175 -178. DOI: 10.29303/jppipa.v5i2.257 
[11] Erik Anderson, C. Ekstrand. 2019. Indium Properties, Uses, Market and Economy, Recovery, and Environmental Impacts. Colorado School of Mines

[12] Ramanathan, G. Murali, K. $\quad$ R. 2015. Characteristics of Tin Doped Indium Oxide Films. International Journal of Chem Tech Research. Vol. 8. (8). 260-264

[13] Seiler, W. Nistor, M. Hebert, C. Perrière, J. 2013. Epitaxial Undoped Indium Oxide Thin Films: Structural and Physical Properties. Journal Solar Energy Materials \& Solar Cells, 116 (2013) 34-42

[14] Sriram, S and Thayumanavan, A.2013. Effect of Al Concentration on the Optical and Electrical Properties of $\mathrm{SnO}_{2}$ Thin Films Prepared by LowCost Spray Pyrolysis Technique. International Journal of ChemTech Research, 5(5): 2204 - 220

[15] Kaur, M. Dadhich, B. Singh, R. Ganpathi, K. Bagwaiya, T. Bhattacharya, S. Debnath, A.K. Muthe, K. P. Gadkari, S.C. 2017. RF sputtered $\mathrm{SnO}_{2}$ : $\mathrm{NiO}$ thin films as sub-ppm $\mathrm{H} 2 \mathrm{~S}$ sensor operable at room temperature. Sensors and Actuators B: Chemical http://dx.doi.org/10.1016/j.snb.2016.11.054

[16] Beatriceveena. T. V. Prabhu, E. Jayaraman, V. Gnanasekar, K. I. 2018. X-ray photoelectron and Hall studies on nanostructured thin films of $\mathrm{PbS}$ grown by pulsed laser deposition. Journal Materials Letters (2018), DOI: https://doi.org/10.1016/j.matlet.2018.12.038

[17] Angarita, G. Palacio, C. Trujillo, M. Arroyave, M. 2017. Synthesis of Alumina Thin Films Using Reactive Magnetron Sputtering Method. IOP Conf. Series: Journal of Physics: Conf. Series, 850 (2017) 012022

[18] Patel, P. Karmakar, A, Chetan Jariwala, C. Ruparelia, J. P. 2013. Preparation and Characterization of $\mathrm{SnO}_{2}$ Thin Film Coating using rf Plasma Enhanced Reactive Thermal Evaporation

[19] Xu, B. Ren, X. G. Gu, G. R. Lan, L. L. Wu, B.J. 2016. Structural and Optical Properties of $\mathrm{Zn}$ doped $\mathrm{SnO}_{2}$ Films Prepared by DC and RF Magnetron Co-Sputtering. Superlattices and Microstructures

[20] Velumani, M. Meher, S. R.. Alex, Z. C. 2017. Impedometric humidity sensing characteristics of $\mathrm{SnO}_{2}$ thin films and $\mathrm{SnO} 2-\mathrm{ZnO}$ composite thin films grown by magnetron sputtering. Journal of Material Science: Material in Electronics

[21] Yongvanich, N. Thongkaew, K. Yuanlae N. Saeung, S. Suwanchawalit C. 2018. Influence of
Copper Doping in Nanostructured ZnO Thin Films by Spin Coating. IEEE Transactions On Nanotechnology, Vol. 17 (6)

[22] Doyan, Susilawati, Ikraman, Taufik, 2018. Characterization of SnO2 Film with Al-Zn Doping Using Sol-Gel Dip Coating Techniques. The International Conference on Theoretical and Applied Physics. IOP Conf. Series: Journal of Physics: Conf. Series, 1011 (2018) 012015

[23] Ariyakkani, P. Lakshmikanthan, S. Balakrishnan, S. 2016. Investigation of the structural, optical, and magnetic properties of $\mathrm{Fe}$ doped $\mathrm{ZnO}$ thin films coated on glass by a sol-gel spin coating method. Journal of Alloys and Compounds (2017), DOI: 10.1016/j.jallcom.2016.12.011

[24] Thirumoorthi, M. Prakash, J. T. J. 2015. A study of Tin doping effects on physical properties of $\mathrm{CdO}$ thin films prepared by a sol-gel spin coating method. Journal of Asian Ceramic Societies xxx (2015) Xxx-Xxx

[25] Kittle, C. 2005. Introduction to Solid State Physics Eighth Edition. California: John Wiley and Sons, Inc

[26] Susilawati. Doyan, A. 2009. Dose-response and optical Properties of Dyed Poly Vinyl AlcoholTrichloroacetic Acid Polymeric Blends Irradiated with Gamma-Rays. American Journal of Applied Science, 6 (12): 2071 -2077, 2009

[27] Pati, S. Banerji, P. Majumder, S. B. 2015. Properties of Indium doped nanocrystalline $\mathrm{ZnO}$ thin films and their enhanced gas-sensing performance. Journal Royal Society of Chemistry (2015) DOI: 10.1039/C5RA10919A

[28] Doyan, A., Susilawati, Hakim, S., Muliyadi, L., Taufik, M., and Nazarudin. 2019. The Effect of Indium Doped $\mathrm{SnO}_{2}$ Thin Films on Optical Properties Prepared by Sol-Gel Spin Coating Technique. Journal of Physics: Conference Series, 1397: $1-8$

[29] Doyan, A., Susilawati, and Imawanti, Y. D. 2017. Synthesis and Characterization of $\mathrm{SnO}_{2}$ Thin Layer with a Doping Aluminum are Deposited on Quartz Substrates. American Institute of Physics, 1801: 17

[30] Bakr, N. A., Salman, S. A. N. Ali, M. N. 2016. Effect of Fluorine Doping on Structural and Optical Properties $\mathrm{SnO}_{2}$ Thin Films Prepared by Chemical Spray Pyrolysis Method. Advances in Materials, 5 (4):23-30 
[31] Sundaram, B. Veeravazhuthi, V. Meena, P. Selvan, K. 2004. Thin Film Technique, and Applications. Mumbai: Allied Publishers PVT. Limited

[32] Mo, Y. W., Kleiner, J., Webb, M. B., \& Lagally, M. G. 1991. Activation energy for surface diffusion of $\mathrm{Si}$ on $\mathrm{Si}(001)$ : A scanning-tunnelingmicroscopy study. Physical Review Letters, 66(15), 1998-2001. doi: 10.1103/physrevlett.66.1998 